\title{
Penerapan Metode Prototype Pada Perancangan Sistem Administrasi Pembayaran Karate Berbasis Website: Studi Kasus Lemkari Prabumulih
}

\author{
Uci Pratiwi, Khana Wijaya \& Fajriyah \\ Sekolah Tinggi Manajemen Informatika dan Komputer Prabumulih \\ Email: Ucipratiwi9707@,Gmail.Com
}

\begin{abstract}
The development of information technology, especially the internet, is certainly welcomed by all circles, one of which has even penetrated the world of organizations. Lemkari Kota Prabumulih is a sports organization located in Prabumulih City which is engaged in the sport of karate. The system applied in several lemkari karate training locations in Prabumulih is still done manually. If a payment transaction occurs, management records the payment into a manual written ledger and only recapitulates the records in Microsoft Office Excel. So that sometimes there are often errors in recording data, errors in recording data for those who have made payments because the participants are mostly small children, the time is reduced due to slow manual data recording so that it is not effective in training due to the slow service of trainers to participants who make payments. Therefore, it is necessary to have a website-based system for every administrative service in order to facilitate the process of good data management and data transparency for trainers, participants, and participants' parents. This website was created using the PHP (Personal Hypertext Preprocessor) programming language with MySQL Database storage and using UML (Unifield Modeling Language) as a design method.
\end{abstract}

Keywords: Website, Lemkari Prabumulih, PHP, MySql.

\section{Pendahuluan}

Perkembangan teknologi informasi khususnya internet tentu disambut baik oleh semua kalangan, salah satunya bahkan telah merambah ke dunia organisasi. Teknologi telah mengalami kemajuan yang sangat pesat dimana banyak terlahir inovasi dan teknologi bernilai tepat guna bagi semua kalangan untuk dapat memanfaatkannya secara optimal. Seperti juga halnya di bidang organisasi olahraga.

Sistem yang berjalan pada beberapa tempat latihan karate Lemkari kota Prabumulih saat ini masih dilakukan secara manual atau konvensional sehingga dikatakan kurang efektif dilihat dari aktivitas yang ada pada bagian administrasi pada salah satu tempat latihan karate Lemkari kota Prabumulih. Bila terjadi transaksi pembayaran, bagian pengurus mencatat pembayaran tersebut kedalam sebuah buku besar yang ditulis secara manual dan hanya melakukan rekapitulasi pencatatan pada Microsoft Office Excel saja. Sehingga terkadang menyebabkan kurang efektif dan sering terjadinya kekeliruan dalam melakukan pencatatan data, kesalahan dalam melakukan pencatatan data bagi yang telah melakukan pembayaran dikarenakan peserta yang rata-rata adalah anak kecil, waktu yang berkurang karena lambat dalam melakukan pencatatan data secara manual sehingga tidak efektif dalam latihan dikarenakan lambatnya pelayanan pelatih terhadap peserta yang melakukan pembayaran, Wali peserta tidak dapat mengetahui apakah uang pembayaran yang diberikan orang tuanya dibayarkan kepihak pelatih atau tidak.

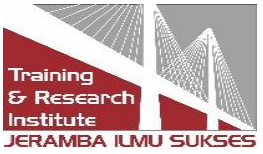


Data dan informasi yang diperoleh dalam suatu pelayanan pembayaran selalu tidak akurat, sehingga tidak mudah untuk diolah dengan cara manual. Oleh karenanya sangat diperlukan sistem berbasis website bagi setiap pelayanan administrasi agar dapat memudahkan proses manajemen data dengan baik dan terjadinya transparansi data terhadap pelatih, peserta, maupun orang tua peserta. Dari latar belakang diatas maka penulis mencoba membuat suatu rancangan sistem administrasi berbasis website yang tepat dan dapat menggantikan pencatatan data secara manual dan konvensional dengan meneliti "Penerapan Metode Prototype Pada Perancangan Sistem Administrasi Pembayaran Karate Berbasis Website (Studi Kasus : Lemkari Kota Prabumulih)”.

\section{Tinjauan Literatur}

\subsection{Pengertian Sistem}

Menurut T.H Astah yang dikutip oleh Abdur Rochman,dkk (2018) dalam jurnal yang berjudul Perancangan Sistem Informasi Administrasi Pembayaran SPP Siswa Berbasis Web di SMK Al-Amanah, "Sistem dapat didefinisikan sebagai sekumpulan objek-objek yang saling berelasi dan berinteraksi, serta hubungan antar objek bisa dilihat sebagai satu kesatuan yang dirancang untuk mencapai satu tujuan yang telah ditetapkan".

\subsection{Pengertian Informasi}

Menurut Tata Sutabri yang dikutip oleh Abdur Rochman, dkk (2018) dalam jurnal berjudul Perancangan Sistem Informasi Administrasi Pembayaran SPP Siswa

Berbasis Web di SMK Al-Amanah, "Informasi adalah data yang telah dilkasifikasikan atau diolah atau di interprestasikan untuk digunakan dalam proses pengambilan keputusan. Sistem pengolah informasi akan mengolah data menjadi informasi atau mengolah data dari bentuk tak berguna menjadi berguna bagi yang menerimanya"

\subsection{Pengertian Sistem Informasi}

Menurut Darmawan Deni dan K.N Fauzi yang dikutip oleh Wahyu Nugraha dan Muhamad Syarif (2018) dalam jurnal berjudul Penerapan Metode Prototype Dalam Perancangan Sistem Informasi Penghitungan Volume dan Cost Penjualan Minuman Berbasis Website, "Sistem Informasi merupakan kumpulan sub-subsistem yang saling berhubungan satu sama lain dan bekerja sama secara harmonis untuk mencapai satu tujuan, yaitu mengelola data menjadi informasi yang berguna".

\subsection{Pengertian Perancangan}

Menurut Mohamad Subhan yang dikutip oleh Dedi Suhendro (2017) dalam jurnal berjudul Perancangan dan Implementasi Realisasi Anggaran Pendapatan (Studi Kasus : Pengadilan Negeri Klas IB Pematangsiantar) "Perancangan adalah proses pengembangan spesifikasi baru berdasarkan rekomendasi hasil analisis sistem".

\subsection{Pengertian Administrasi}

Menurut Affifuddin (2010:3) dalam bukunya yang berjudul Pengantar Administrasi Pembangunan. "Administrasi dalam arti sempit, yaitu berasal dari kata Administratie (bahasa Belanda), yang meliputi kegiatan : catat-mencatat, surat-menyurat, pembukuan ringan, ketik-mengetik, kegiatan menyusun keterangan-keterangan secara sistematik, dan pencatatan-pencatatannya secara tertulis untuk didokumentasikan, agar mudah

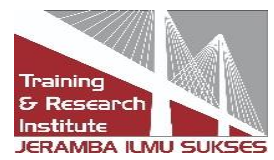


menemukannya bilamana akan dipergunakan lagi, baik secara terpisah-pisah maupun sebagai keseluruhan yang tidak terpisahkan, dan segala sesuatu yang bersifat teknis ketatausahaan (clerical work). Jadi pengertian administrasi sebagai ketatausahaan (clerical work) merupakan sebagian kecil dari administrasi".

\subsection{Pengertian Pembayaran}

Menurut Ageng Setiani Rafika, dkk (2017) dalam jurnal berjudul Sistem Pembayaran Rincian Biaya Kuliah Pada Perguruan Tinggi Raharja Menggunakan Go+ "Pembayaran adalah berpindahnya hak pemilikan atas sejumlah uang atau dan dari pembayar kepada penerimanya, baik langsung maupun melalyui media jasa-jasa perbankan".

\subsection{Pengertian Karate}

Menurut Muhammad Rhadian (2018:3) dalam bukunya yang berjudul Karate "Karate berasal dari bahasa jepang. Karate terdiri dari dua kata, yaitu kara dan te, kara berarti kosong, sedangkan te berarti tangan. Jadi, karate diartikan sebagai tangan kosong. Biasanya pengguna kata karate diikuti pula dengan kata $d o$. Dalam hal ini, do berarti seni. Kemudian, karate menjadi karate-do. Artinya, seni beladiri dengan menggunakan tangan kosong".

\subsection{Pengertian Website}

Menurut Yoka Ifana Putra (2015:69) dalam buku berjudul 1 Jam Pasti Bisa Membuat Website Gratis Otodidak Tanpa Guru. "Website merupakan suatu kumpulan dari halamanhalaman situs, yang terangkum dalam sebuah domain atau subdomain, yang tempatnya berada di dalam World Wide Web $(W W W)$ di dalam internet".

\subsection{Pengertian PHP ( Personal Hypertext Pre Processor)}

Menurut E.W. ST, M.Eng dan Z.Ali yang dikutip oleh Abdur Rochman, dkk (2018) “PHP adalah bahasa pemograman scripting yang pertama dikembangkan untuk meng-generate statement HTML. Bahkan program yang dikembangkan dengan PHP seratus persen, tetap ditampilkan dalam bentuk kode $H T M L$ "

\subsection{Pengertian MYSQL}

Menurut Budi Raharjo yang dikutip oleh Andi Christian, dkk (2018) dalam jurnal yang berjudul Rancang Bangun Website Sekolah Dengan Menggunakan Framework Bootstrap (Studi Kasus SMP Negeri 6 Prabumulih). "MySQL merupakan software RDBMS (server database) yang dapat mengelola database dengan sangat cepat, dapat menampung data dalam jumlah sangat besar, dapat diakses oleh banyak user (multi-user) dan dapat melakukan suatu proses secara sinkron atau berbarengan (multi-threaded)".

\subsection{Pengertian Basis Data}

Menurut Ganda Yoga Swara dan Yunes Pebriadi (2016) dalam jurnal berjudul Rekayasa Perangkat Lunak Pemesanan Tiket Bioskop Berbasis Web. "Basis data atau Database adalah kumpulan informasi yang disusun dan merupakan suatu kesatuan yang utuh yang disimpan di dalam perangkat keras (komputer) secara sistematis sehingga dapat diolah menggunakan perangkat lunak".

\subsection{Pengertian XAMPP}

Menurut Randi V. Palit, dkk (2015) dalam jurnal yang berjudul Rancangan Sistem

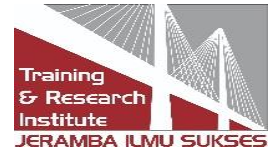


Informasi Keuangan Gereja Berbasis Web Di Jemaat GMIM Bukit Moria Malalayang. "XAMPP adalah perangkat lunak bebas, yang mendukung banyak sistem operasi, merupakan kompilasi dari beberapa program".

\section{Metode Penelitian}

\subsection{Objek Penelitian}

Menurut Arikunto yang dikutip oleh Muhammad Fauzan (2017) menyatakan bahwa "objek adalah sesuatu yang melekan dan dipermasalahkan". Penelitian ini dilakukan di salah satu tempat latihan karate Lemkari kota Prabumulih Bertempat di SDN 39 Prabumulih Jalan Mawar Kelurahan Gunung Ibul Kecamatan Prabumulih Timur kota Prabumulih.

\subsection{Struktur Organisasi}

Adapun struktur organisasi Lemkari Kota Prabumulih adalah sebagai berikut :

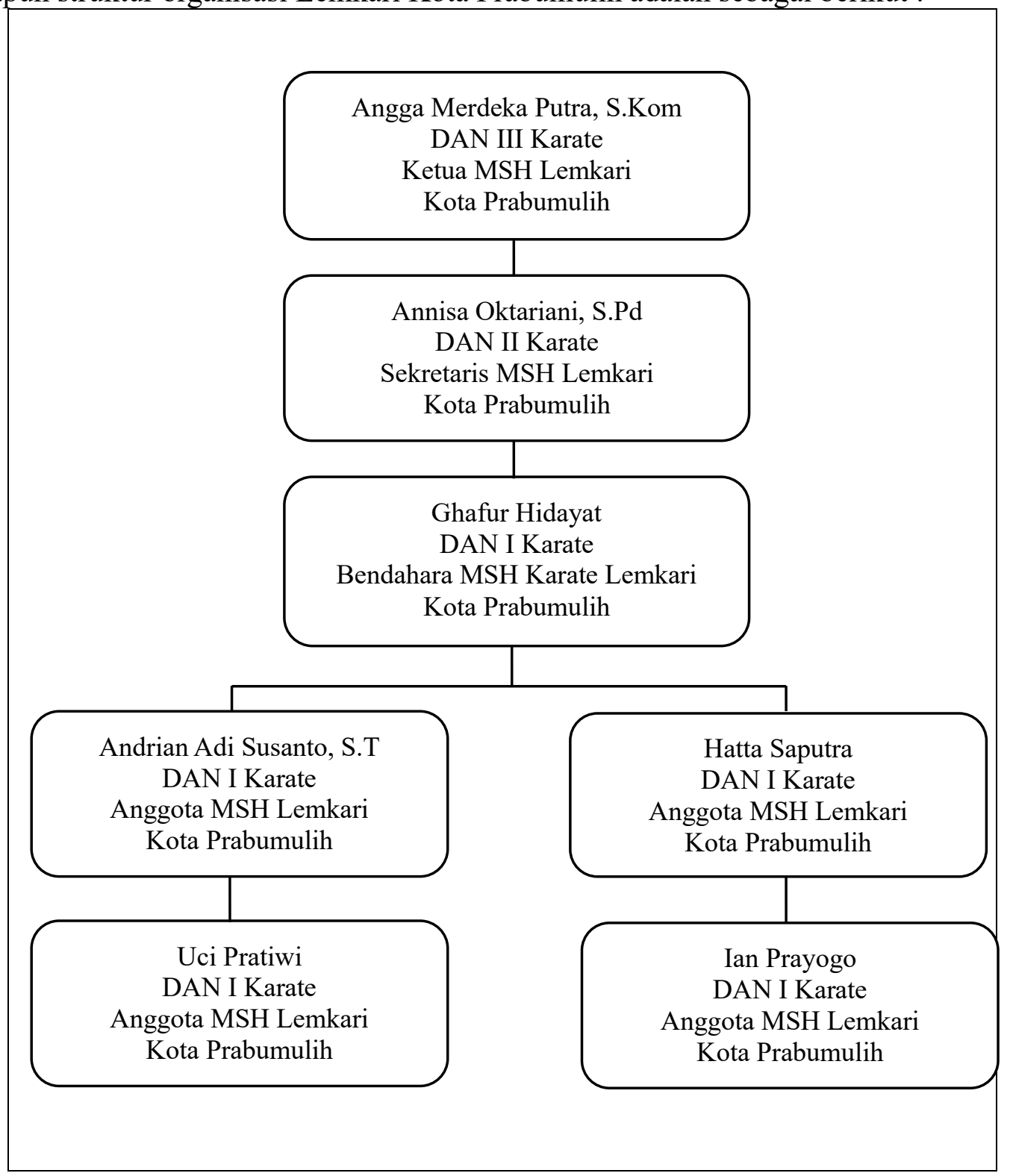

Gambar 3.1 Struktur Organisasi

Published by:

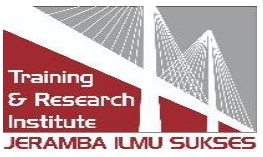




\subsection{Metode Penelitian}

Metode penelitian yang digunakan penulis adalah metode penelitian deskriptif melalui pendekatan kualitatif. Menurut Nazir dan Moh yang dikutip oleh Iwan Setiawan, dkk (2018) dalam jurnal yang berjudul Perancangan Sistem Administrasi Perumahan Pada PT.Gunung Berlian Nusantara Prabumulih, "Metode deskriptif adalah suatu metode dalam meneliti status sekelompok manusia, suatu objek, suatu set kondisi, suatu sistem pemikiran ataupun suatu kelas peristiwa pada masa sekarang". Tujuan dari penelitian deskriptif ini adalah untuk membuat deskripsi, gambaran, atau lukisan secara sistematis, faktual dan akurat mengenai fakta-fakta, sifat-sifat serta hubungan antar fenomena yang diselidiki (Iwan Setiawan, dkk : 2018). Sedangkan menurut Parker yang dikutip oleh Zul Azmi, Abdillah Arif N, Wardayani (2018) dalam jurnal yang berjudul Memahami Penelitian Kualitatif Dalam Akuntansi. "Metode penelitian kualitatif menggunakan data kualitatif seperti wawancara, data observasi partisipan dan data dokumen untuk memahami dan menjelaskan fenomena sosial".

Metode penelitian deskriptif melalui pendekatan kualitatif yang digunakan pada penelitian ini dimaksudkan untuk mempermudah dalam melakukan kegiatan administrasi pencatatan pembayaran pada tempat latihan karate Lemkari kota Prabumulih.

\subsection{Metode Pengembangan Sistem}

Metode yang digunakan dalam pengembangan sistem ini adalah metode Prototype. Menurut Rosa A.S dan M. Shalahuddin yang dikutip oleh Iwan Setiawan, dkk (2018) dalam jurnal yang berjudul Perancangan Sistem Administrasi Perumahan Pada PT.Gunung Berlian Nusantara Prabumulih, "Model prototype dapat digunakan untuk menyambungkan ketidakpahaman pelanggan mengenai hal teknis dan memperjelas spesifikasi kebutuhan yang diinginkan pelanggan kepada pengembang perangkat lunak".

Menurut Malatista, dkk yang dikutip oleh Siti Nurajizah (2015) dalam jurnal berjudul Sistem Informasi Perpustakaan Berbasis Web Dengan Metode Prototype: Studi Kasus Sekolah Islam Gema Nurani Bekasi "Dasar dari pemikiran ini adalah membuat prototipe secepat mungkin, bahkan dalam waktu semalam, lalu memperoleh umpan balik dari pengguna yang akan memungkinkan prototype tersebut diperbaiki kembali dengan sangat cepat. Semua rancangan diagaram atau model yang dibuat tidak diharuskan telah sempurna dan final dalam pendekatan prototype. Tujuan utama dari penyiapan rancangan adalah sebagai alat bantu dalam memberi gambaran sistem seperti materi dan menu yang perlu dimasukkan dalam prototype yang akan dikembangkan. Setelah rancangan terbentuk, dilanjutkan dengan mulai mengembangkan prototype”. 


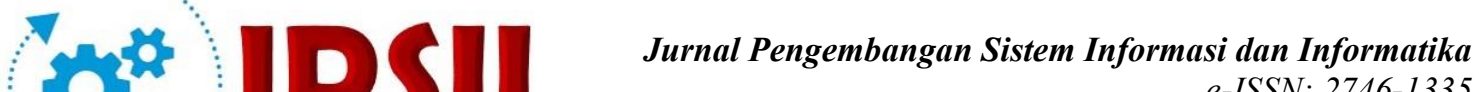

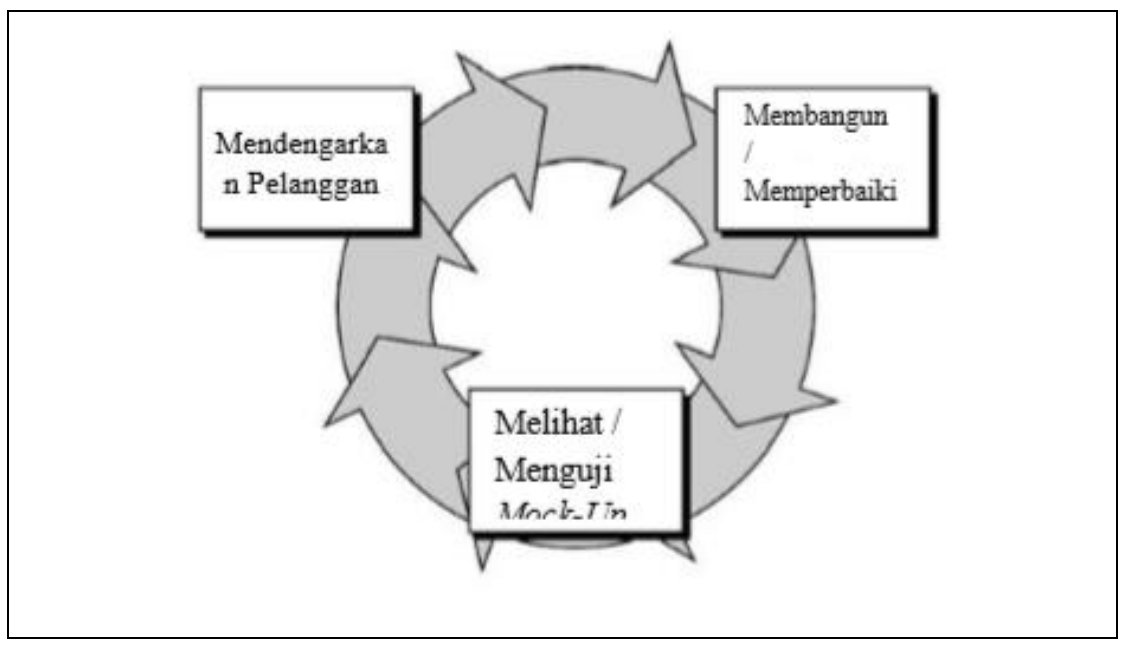

Gambar 3.2 Tahapan Metode Prototype

Sumber : Rosa dan Shalahuddin dikutip oleh Eko Prastiyo (2016)

\subsection{Metode Perancangan Sistem}

Metode perancangan sistem yang digunakan dalam penelitian ini adalah sebagai berikut :

\subsubsection{UML (Unifield Modelling Language)}

Menurut Riska Noviastuty (2019) dalam jurnal berjudul Perancangan Sistem Integrasi Administrasi dan Keuangan Dalam Pelayanan Tera dan Tera Ulang Timbangan, "UML merupakan metodologi pemodelan berorientasi objek yang digunakan untuk melakukan perancangan sebuah sistem. $U M L$ sendiri terdiri dari himpunan struktur dan teknik untuk pemodelan desain program yang berorientasi objek. $U M L$ berfungsi sebagai bahasa untuk menentukan, memvisualisasikan, membangun, mendokumentasikan dalam suatu sistem informasi".

\section{Use Case Diagram}

Menurut Munawar yang dikutip oleh Siti Nurajizah (2015) dalam jurnal berjudul Sistem Informasi Perpustakaan Berbasis Web Dengan Metode Prototype: Studi Kasus Sekolah Islam Gema Nurani Bekasi, "Use Case Diagram digunakan untuk menyatakan fungsionalitas yang disediakan oleh suatu organisasi secara keseluruhan dan digunakan secara intensif untuk menghimpun konteks sistem".

\begin{tabular}{|l|c|c|l|}
\multicolumn{3}{|c}{ Tabel 3.1 Simbol Use Case Diagram } \\
\hline NO & SIMBOL & NAMA & \multicolumn{1}{c|}{ KETERANGAN } \\
\hline 1 & $\begin{array}{c}\text { Nama Use } \\
\text { Case }\end{array}$ & Use Case & $\begin{array}{l}\text { Fungsionalitas yang disediakan } \\
\text { sistem sebagai unit-unit yang saling } \\
\text { bertukar pesan antar unit dan aktor. }\end{array}$ \\
\hline 2 & & $\begin{array}{l}\text { Orang, proses, atau sistem lain yang } \\
\text { berinteraksi dengan sistem informasi } \\
\text { yang akan dibuat diluar sistem }\end{array}$ \\
\hline
\end{tabular}




\begin{tabular}{|c|c|c|c|}
\hline & P & Actor & informasi. \\
\hline 3 & & Assosiation & $\begin{array}{l}\text { Komunikasi antar aktor dan Use Case } \\
\text { yang berpartisipasi. }\end{array}$ \\
\hline 4 & $<<$ extend $>>$ & Ekstensi/extend & $\begin{array}{l}\text { Relasi Use Case tambahan ke } \\
\text { sebuah Use Case dimana Use Case } \\
\text { yang ditambah dapat berdiri sendiri } \\
\text { walau tanpa Use Case tambahan. }\end{array}$ \\
\hline 5 & & Generalisasi & $\begin{array}{l}\text { Hubungan generalisasi } \\
\text { spesialisasi antara dua buah } \\
\text { Case yang mana fungsi yang satu } \\
\text { lebih umum dari yang lainnya. }\end{array}$ \\
\hline 6 & $\underset{\text { uses }}{\stackrel{\langle\text { include }\rangle>}{\longrightarrow}}$ & Include/Use Case & $\begin{array}{l}\text { Relasi Use Case tambahan ke sebuah } \\
\text { Use Case dimana Use Case yang } \\
\text { ditambahkan memerlukan Use Case } \\
\text { ini untuk menjalankan fungsinya }\end{array}$ \\
\hline
\end{tabular}

Sumber : Shalahuddin dan Rosa (2013)

2. $\quad$ Activity Diagram

Menurut Munawar yang dikutip oleh Siti Nurajizah (2015) dalam jurnal berjudul Sistem Informasi Perpustakaan Berbasis Web Dengan Metode Prototype: Studi Kasus Sekolah Islam Gema Nurani Bekasi, "Activity diagram adalah teknik untuk menggambarkan logika prosedural, proses bisnis, dan jalur kerja”.

Tabel 3.2 Simbol Activity Diagram

\begin{tabular}{|l|l|l|l|}
\hline NO & SIMBOL & NAMA & KETERANGAN \\
\hline
\end{tabular}




\begin{tabular}{|c|c|c|}
\hline 1 & Status awal & $\begin{array}{l}\text { Status awal aktivitas pada } \\
\text { sebuah diagram aktivitas } \\
\text { memiliki sebuah status awal. }\end{array}$ \\
\hline 2 & Aktivitas & $\begin{array}{lr}\text { Aktivitas } & \text { yang } \\
\text { dilakukan } & \text { sistem, } \\
\text { aktivitas biasanya } \\
\text { diawali dengan kata } \\
\text { kerja. }\end{array}$ \\
\hline \multirow[t]{2}{*}{3} & & \\
\hline & Percabangan/join & $\begin{array}{l}\text { Asosiasi percabangan dimana } \\
\text { jika ada pilihan aktivitas lebih } \\
\text { dari satu. }\end{array}$ \\
\hline 4 & Penggabungan/join & $\begin{array}{l}\text { Asosiasi penggabungan dimana } \\
\text { lebih dari satu aktivitas } \\
\text { digabungkan menjadi satu. }\end{array}$ \\
\hline 5 & Status akhir & $\begin{array}{l}\text { Status akhir yang dilakukan } \\
\text { sistem, sebuah diagram aktivitas } \\
\text { memiliki sebuah status akhir. }\end{array}$ \\
\hline
\end{tabular}

Sumber : Shalahuddin dan Rosa (2013)

\section{Class Diagram}

Menurut Munawar yang dikutip oleh Siti Nurajizah (2015) dalam jurnal berjudul Sistem Informasi Perpustakaan Berbasis Web Dengan Metode Prototype: Studi Kasus Sekolah Islam Gema Nurani Bekasi, "Class diagram mengambarkan struktur dan deskripsi class, package dan objek beserta hubungan satu sama lain. Class memiliki tiga area pokok: Nama (atau stereotype), Atribut dan metode".

Tabel 3.3 Simbol Class Diagram

\begin{tabular}{|l|c|c|l|}
\hline NO & SIMBOL & \multicolumn{1}{|c|}{ NAMA } & \multicolumn{2}{|c|}{ KETERANGAN } \\
\hline 1 & & Kelas & Kelas pada struktur system \\
\hline 2 & & Antarmuka/Interface & $\begin{array}{l}\text { Sama dengan interface ronsep } \\
\text { pemrograman berorientasi } \\
\text { objek. }\end{array}$ \\
\hline 3 & Nama_interface & Asosiasi / association & Relasi antarkelas dengan \\
\hline
\end{tabular}




\begin{tabular}{|c|c|c|c|}
\hline & & & $\begin{array}{l}\text { makna umum, asosiasi } \\
\text { biasanya disertai dengan } \\
\text { multiplicity }\end{array}$ \\
\hline 4 & & $\begin{array}{l}\text { Asosiasi berarah/directed } \\
\text { association }\end{array}$ & $\begin{array}{l}\text { Relasi antarkelas dengan } \\
\text { makna kelas yang satu } \\
\text { digunakan oleh kelas yang } \\
\text { lain, asosiasi biasanya juga } \\
\text { disertai dengan multiplicity. }\end{array}$ \\
\hline 5 & & Generalisasi & $\begin{array}{lr}\text { Relasi antarkelas dengan } \\
\text { makna } & \text { generalisasi } \\
\text { spesialisasi (umum khusus). }\end{array}$ \\
\hline 6 & $-\cdots-\cdots$ & Kebergantungan/depedency & $\begin{array}{lr}\text { Relasi antarkelas dengan } \\
\text { makna } & \text { kebergantungan } \\
\text { antarkelas. } & \end{array}$ \\
\hline 7 & & Agresiasi/aggregation & $\begin{array}{l}\text { Relasi antarkelas dengan } \\
\text { makna semua-bagian. }\end{array}$ \\
\hline
\end{tabular}

Sumber : Shalahuddin dan Rosa (2013)

\section{Hasil dan Pembahasan}

\subsection{Implementasi}

Implementasi merupakan tahapan penerapan sistem diharapkan sistem dapat dioperasikan dengan semaksimal mungkin. Tahap impementasi ini menjelaskan tentang inplementasi perangkat lunak, implementasi perangkat keras, implementasi basis data, implementasi antar muka serta pembahasannya.

\subsubsection{Implementasi Perangkat Lunak}

Dalam mendukung sistem yang diusulkan dapat berjalan optimal sesuai dengan yang diinginkan, dibutuhkan software pengelolaaan data, perangkat lunak yang digunakan untuk mendukung pembuatan website ini, perangkat lunak yang dimaksud yaitu :

1. Sistem Operasi Windows 10

2. Php MySql

3. Notepad ++

4. Xampp Control Panel

\subsubsection{Implementasi Perangkat Keras}

Perangkat keras (hardware) merupakan perangkat yang digunakan sebagai media (alat bantu) untuk menjalankan perangkat lunak (software) dan peralatan ini berfungsi untuk menjalankan perintah program atas apa yang diperintahkan oleh manusia. 
Berikut perangkat keras yang digunakan dalam menjalankan program sebagai pendukung pembuatan program website ini adalah laptop Asus, processor AMD A8-7410 APU with AMD Radeon R 5 Graphics, memory 4096 RAM.

\subsubsection{Implementasi Basis Data}

Perangkat lunak yang dihasilkan dalam penelitian ini dalam bentuk website yang diimplementasikan pada Lemkari Prabumulih dengan menggunakan database mysql, perangkat lunak yang dihasilkan terdiri dari database karate yang memiliki beberapa tabel, seperti tabel bayar, tabel kohai, tabel pelatih, tabel photovideo, dan tabel user.

\subsubsection{Implementasi Antar Muka}

Implementasi antar muka dalam hal ini menerapkan tampilan yang akan dilihat oleh user dilakukan dengan cara membuat desain antar muka pada form yang ada pada website ini. Adapun implementasi antar muka ini harus sesuai dengan keinginan objek yang bersangkutan agar program yang dibuat dapat langsung dimengerti objek sehingga program yang dibuat pun dapat segera digunakan. Berikut yang termasuk dalam implementasi antar muka adalah sebagai berikut :

\section{Tampilan Form Login}

Berikut ini merupakan tampilan form login dengan nama loginkarate.php :

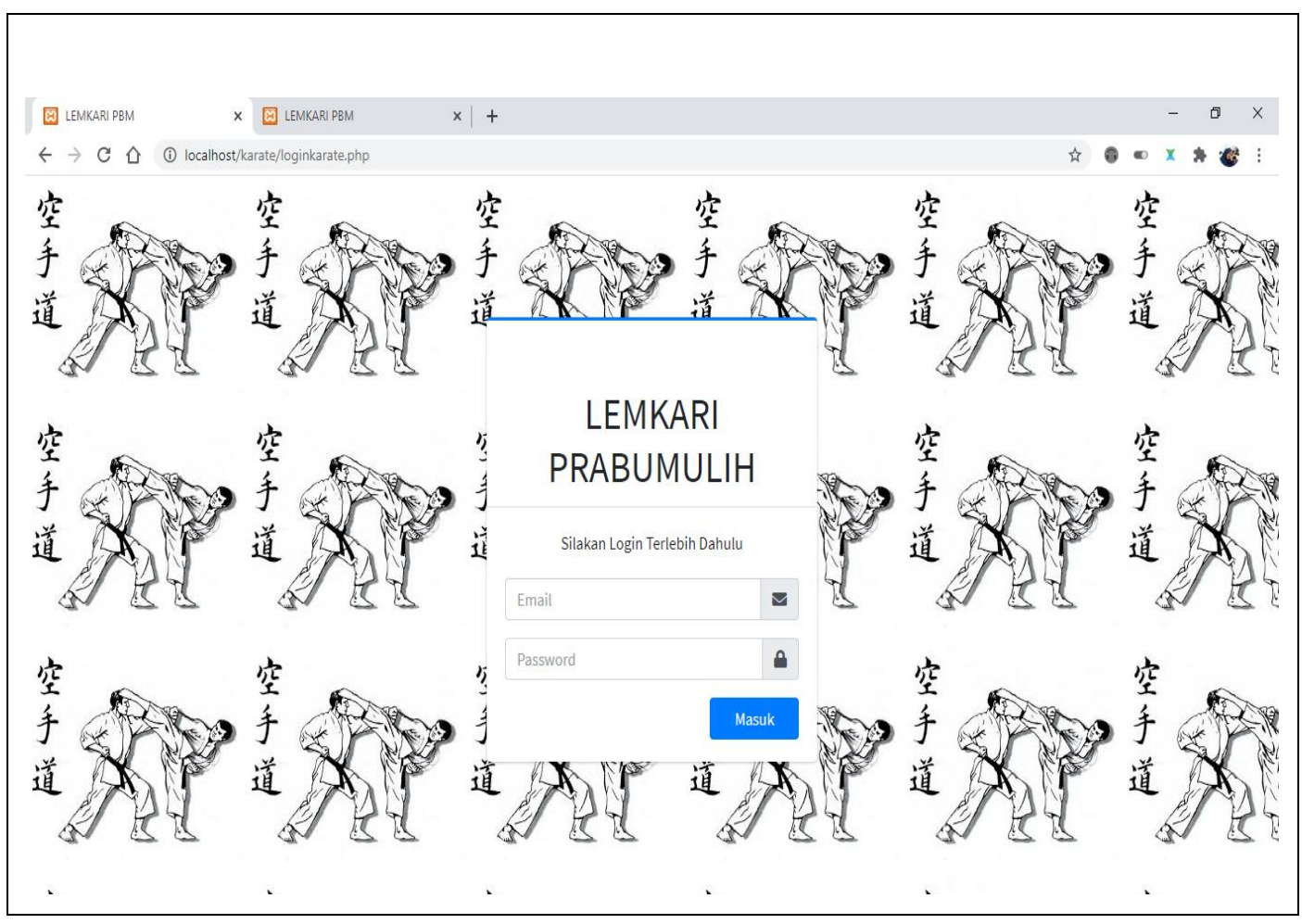

Gambar 4.1 Tampilan Form Login

Pada tampilan form login ini merupakan tampilan login yang dimana admin dan user dapat mesuk ke halaman utama dengan cara mengisi form login berdasarkan pada yang tertera username dan password isi dengan benar, kemudian tekan tombol masuk, maka otomatis akan masuk ke halaman utama dengan tampilan yang hampir sama. User akan

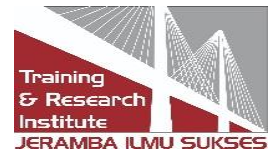


mendapatkan username dan password secara langsung oleh admin maupun pelatih sehingga user akan mudah masuk kedalam sebuah website administrasi Lemkari Prabumulih. Admin akan masuk ke halaman utama admin sedangkan user akan masuk ke halaman utama user apabila pengisian dilakukan dengan benar sesuai dengan nama username dan password yang ada dalam database.

2. Tampilan Halaman Utama Admin

Berikut ini merupakan tampilan halaman utama admin dengan nama karate.php :

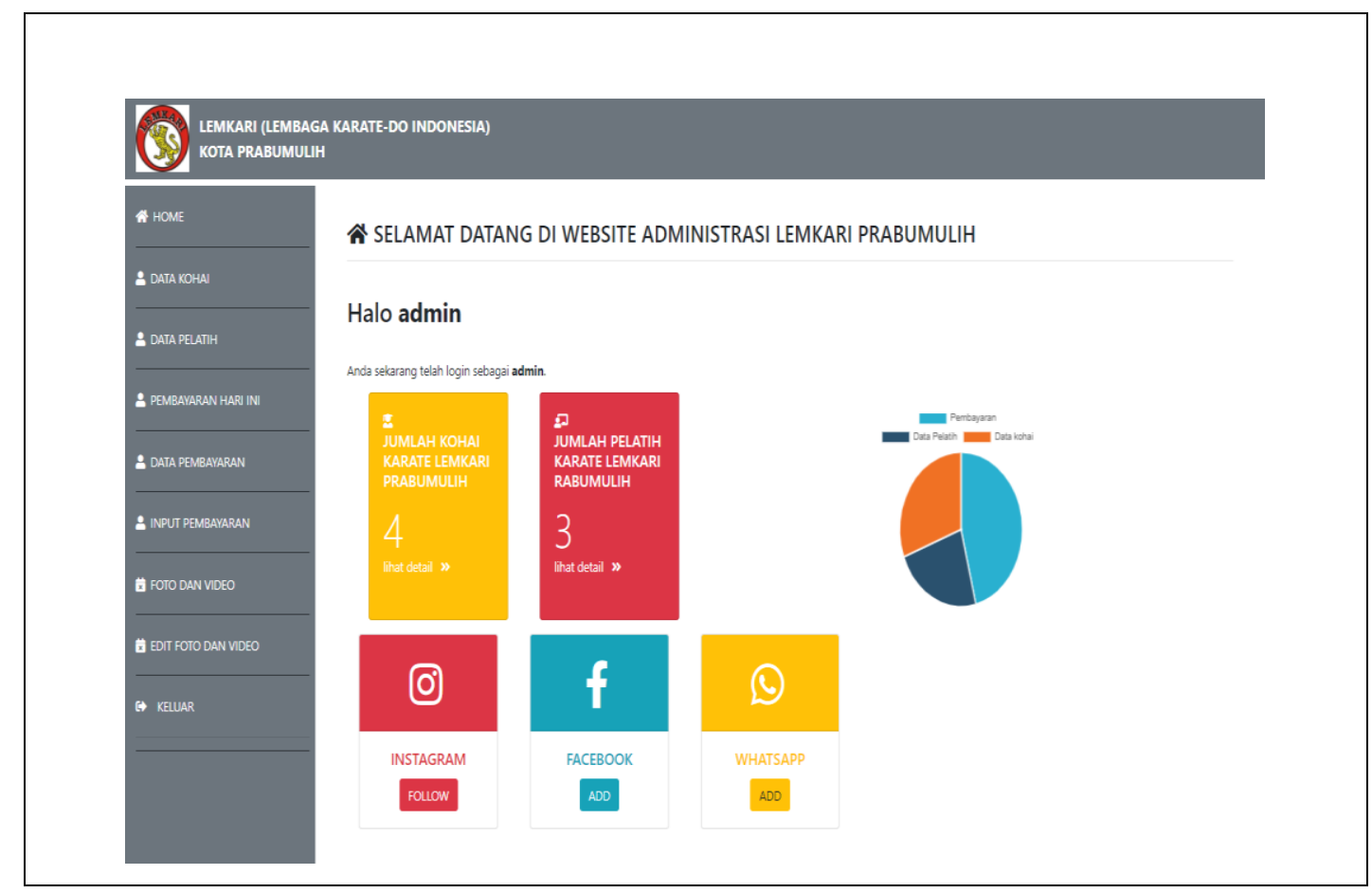

Gambar 4.2 Tampilan Halaman Utama Admin

Pada tampilan halaman utama admin ini merupakan sebuah halaman utama bagi admin yang sudah melakukan login dengan benar. Pada halaman ini admin ataupun pelatih dapat memilih menu pada sidebar yang sudah disediakan pada halaman utama tersebut.

\section{Tampilan Halaman Utama User}

Berikut ini merupakan tampilan halaman utama user dengan nama karatepengunjung.php : 

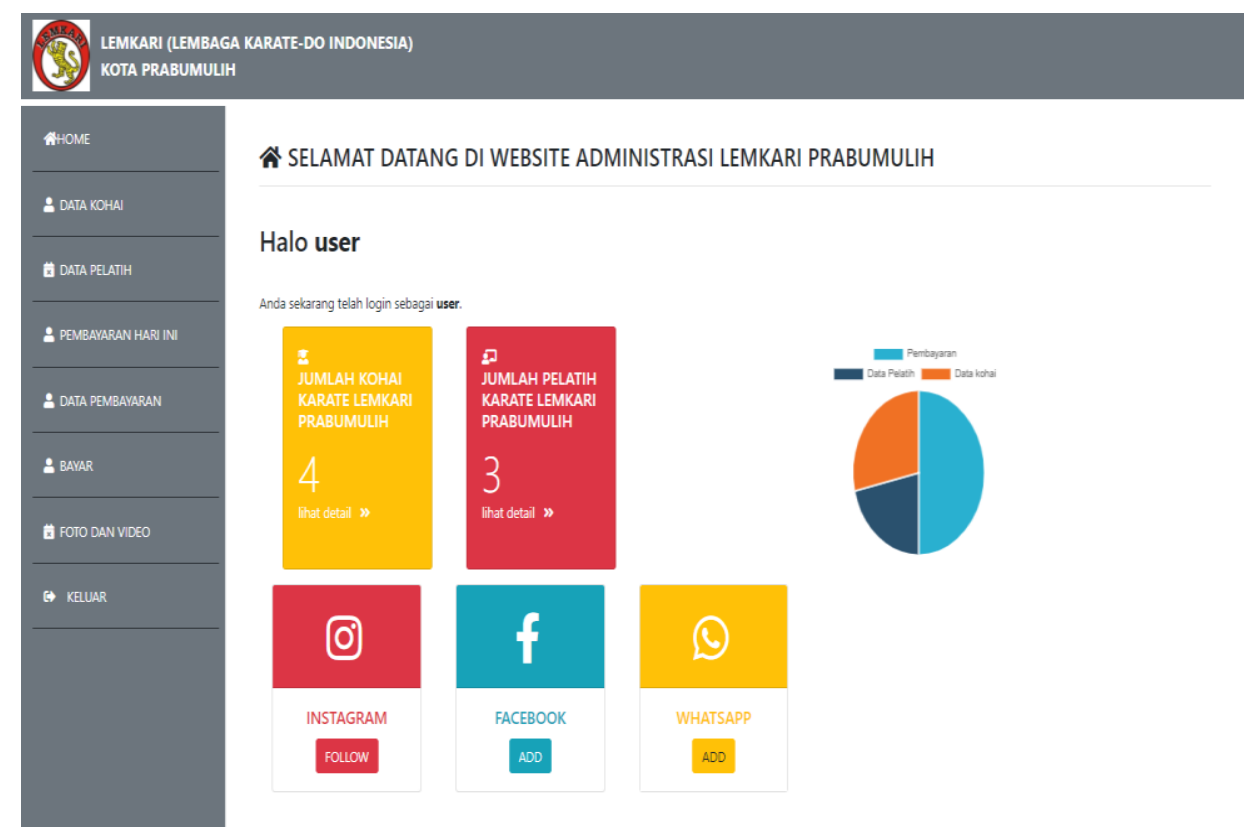

ヘิ SELAMAT DATANG DI WEBSITE ADMINISTRASI LEMKARI PRABUMULIH

Halo user
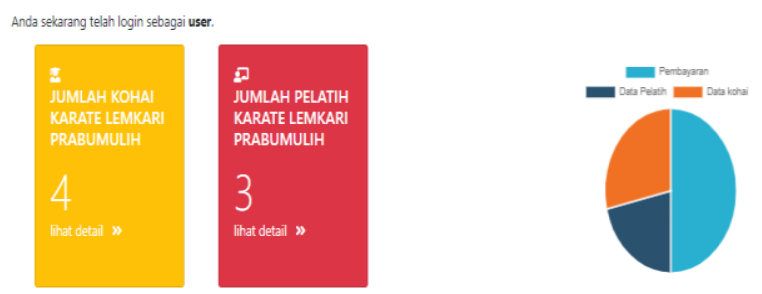

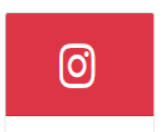

INSTAGRAM

FOLIOW

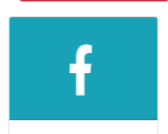

FACEBOOK

$\triangle D D$

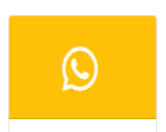

WHATSAPP

ADO

Gambar 4.3 Tampilan Halaman Utama User

Pada tampilan halaman utama user ini merupakan sebuah halaman utama bagi user ataupun peserta yang sudah melakukan login dengan benar. Pada halaman ini user dapat memilih menu pada sidebar yang sudah disediakan pada halaman utama tersebut.

4. Tampilan Form Tambah Data Kohai Pada Halaman Admin

Berikut ini merupakan tampilan Form Tambah Data Kohai Pada Halaman Admin dengan nama input_kohail.php :

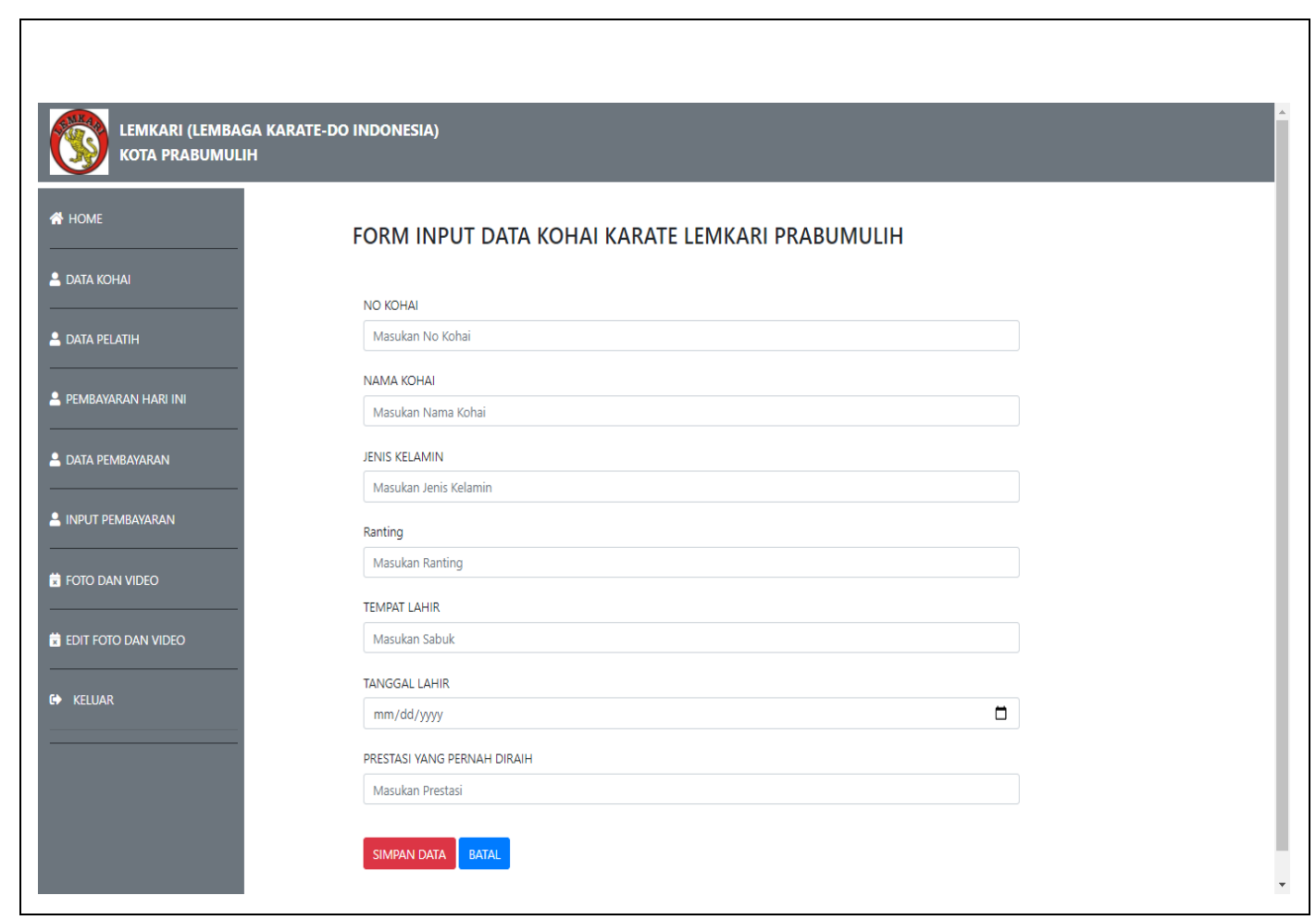

Published by:

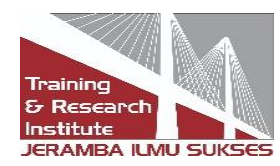


Gambar 4.5 Tampilan Form Tambah Data Kohai Pada Halaman Admin

Pada Tampilan Form Tambah Data Kohai Pada Halaman Admin ini merupakan sebuah halaman form input data kohai pada halaman admin. Admin dapat melakukan input data kohai dengan cara mengisi form yang ada pada halaman tersebut.

5. Tampilan Menu Data Pelatih Pada Halaman Admin

Berikut ini merupakan tampilan Menu Data Pelatih Pada Halaman Admin dengan nama pelatih1.php :

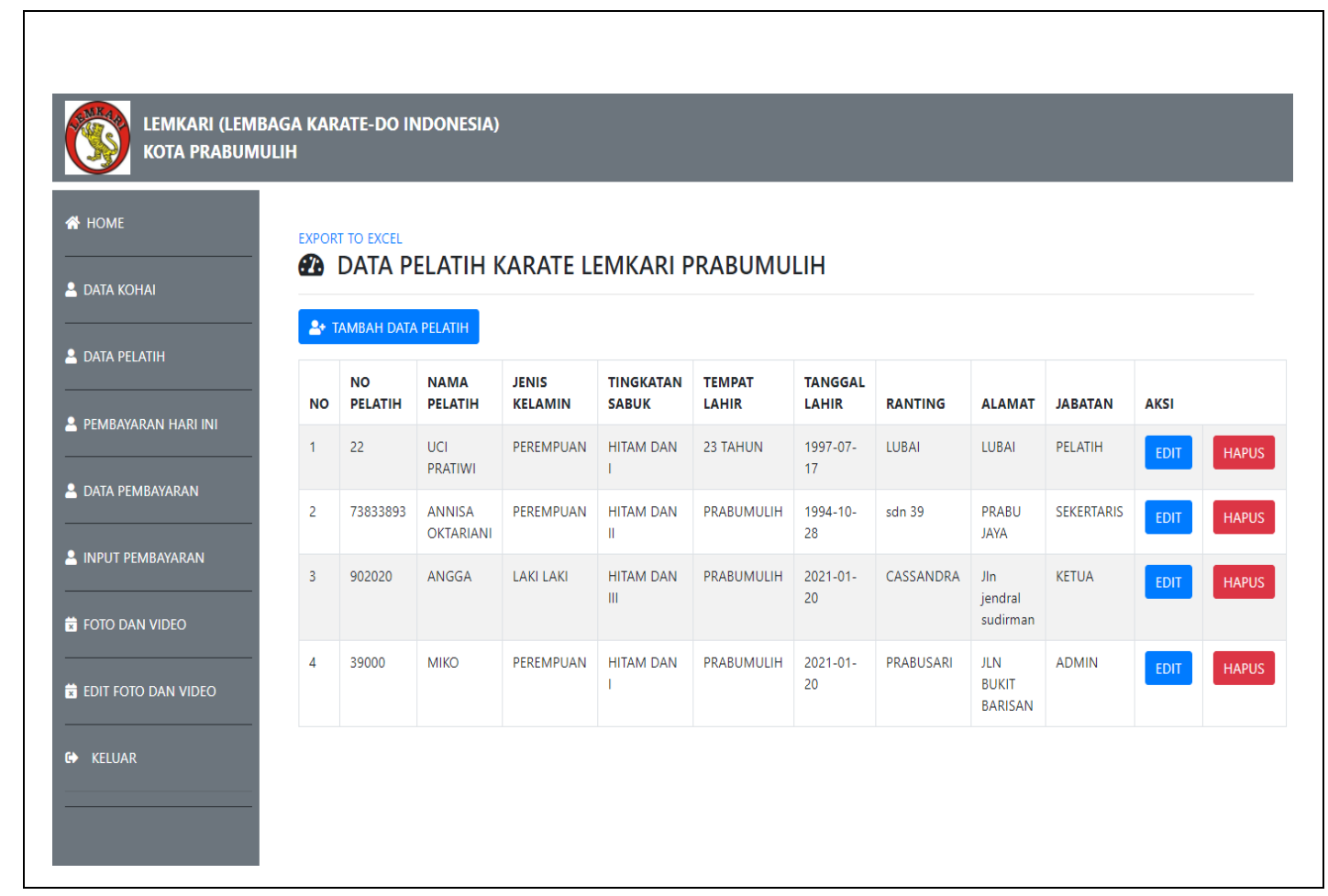

Gambar 4.6 Tampilan Menu Data Pelatih Pada Halaman Admin

Pada Tampilan Menu Data Pelatih Pada Halaman Admin ini merupakan sebuah halaman form input data pelatih pada halaman admin. Admin dapat melakukan input data pelatih dengan cara mengisi form yang ada pada halaman tersebut. Dalam halaman ini pelatih atau admin dapat melakukan tambah data, edit, atau hapus data pelatih.

6. Tampilan Menu Data Pelatih Pada Halaman User

Berikut ini merupakan tampilan Menu Data Pelatih Pada Halaman User dengan nama pelatih2.php : 


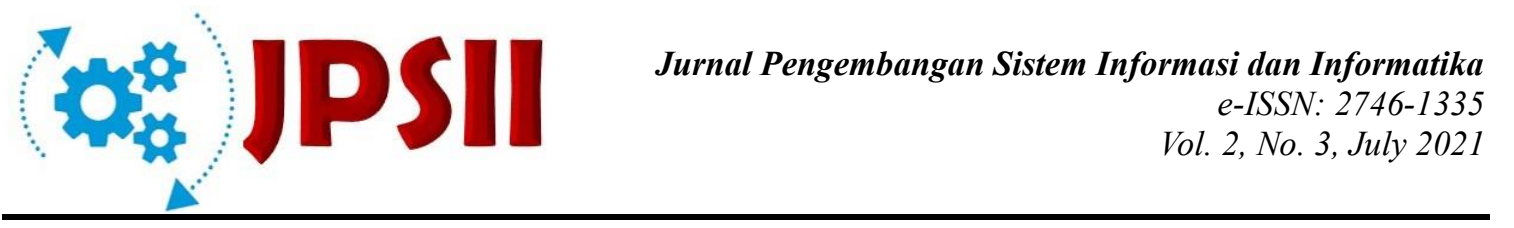

LEMKARI (LEMBAGA KARATE-DO INDONESIA)

KOTA PRABUMULIH

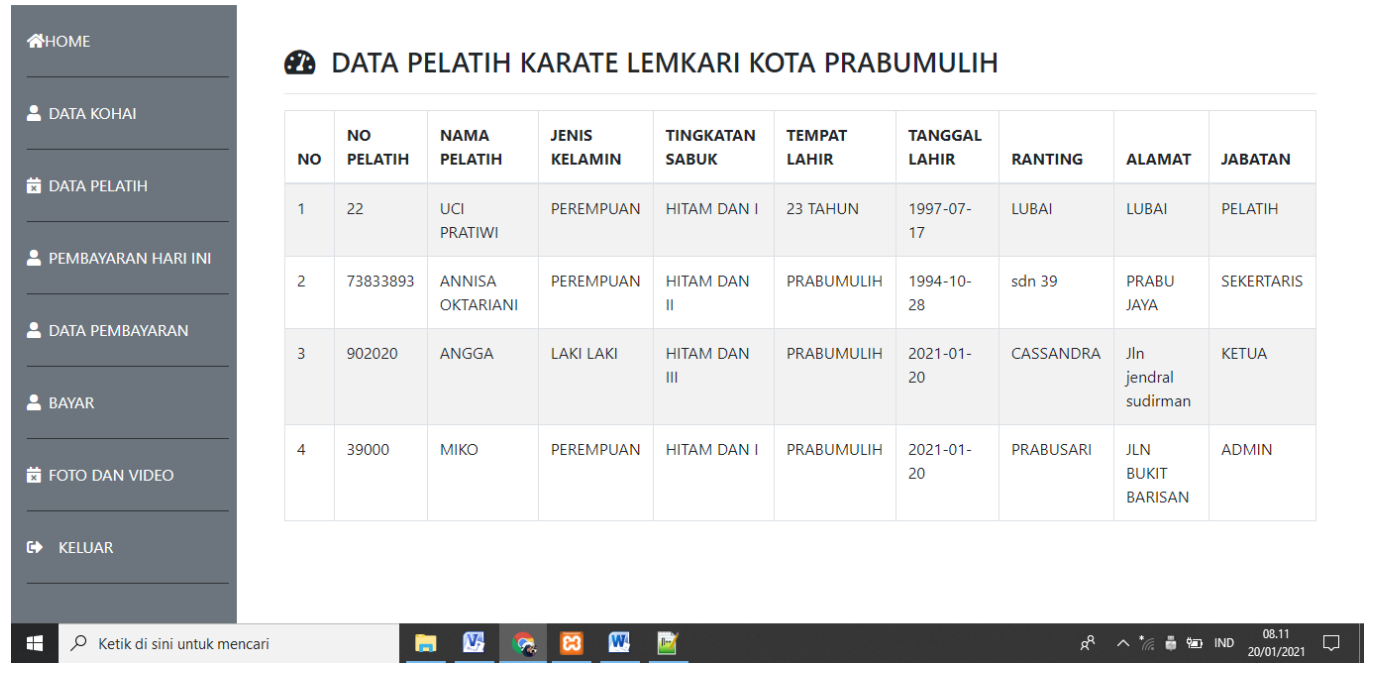

Gambar 4.7 Tampilan Menu Data Pelatih Pada Halaman User

Pada Tampilan Menu Data Pelatih Pada Halaman User ini merupakan sebuah halaman menu data pelatih yang dapat dilihat oleh user setelah user memilih menu data pelatih. Pada halaman ini merupakan halaman yang berisi data pelatih yang sudah diinput oleh admin atau pelatih.

7. Tampilan Menu Pembayaran Hari Ini Pada Halaman Admin

Berikut ini merupakan tampilan Menu Pembayaran Hari Ini Pada Halaman Admin dengan nama tampilpembayaran.php :

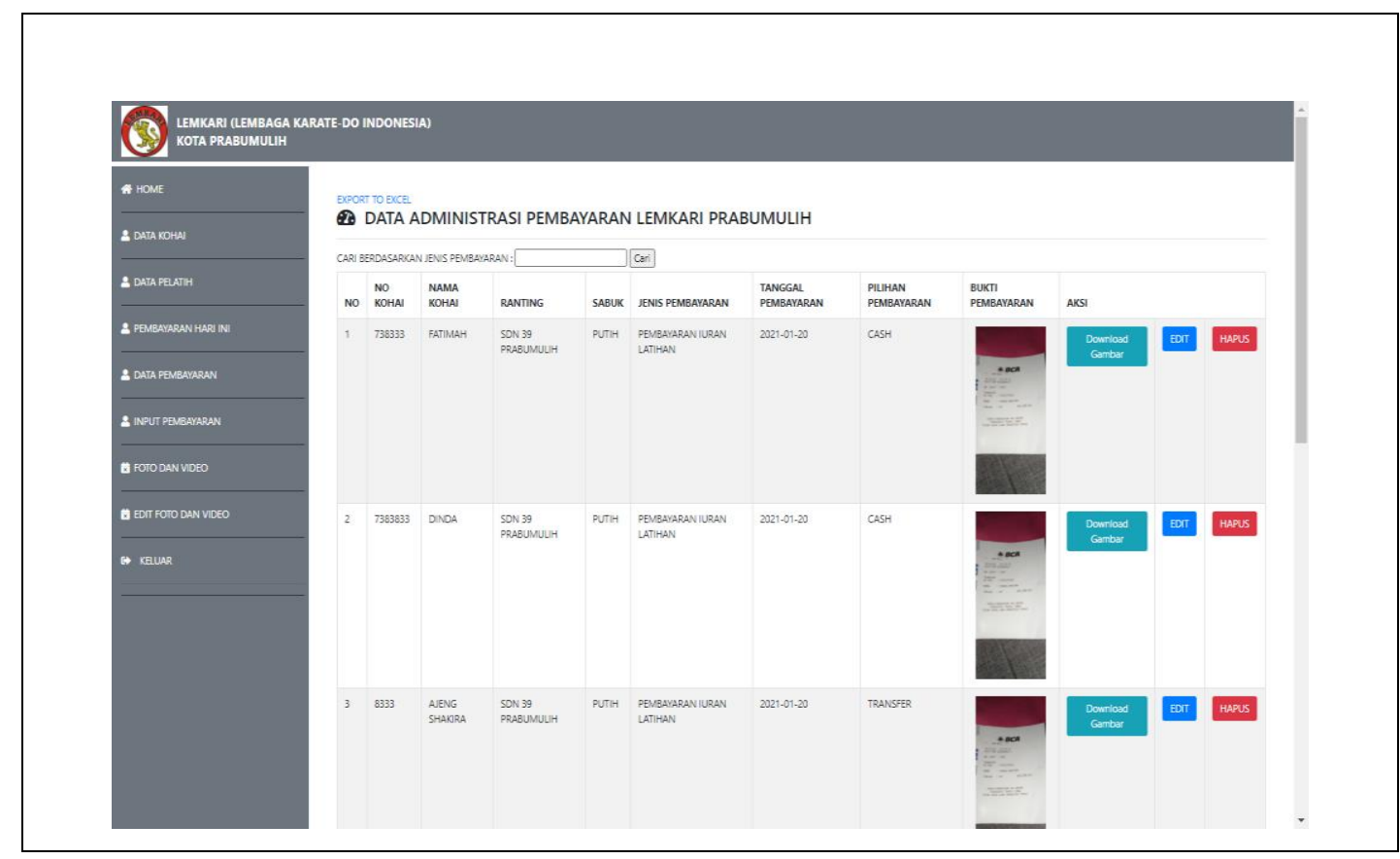

Gambar 4.8 Tampilan Menu Pembayaran Hari Ini Pada Halaman Admin

Published by:

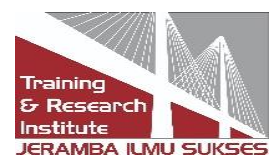


Pada Tampilan Menu Pembayaran Hari Ini Pada Halaman Admin ini merupakan sebuah halaman Menu Pembayaran Hari Ini Pada Halaman Admin dengan memilih menu Pembayaran Hari Ini. Admin dapat melihat data kohai/peserta hari ini yang sudah melakukan pembayaran secara cash ataupun transfer kepada rekening salah satu pelatih yang sudah tertera.

8. Tampilan Menu Pembayaran Hari ini Pada Halaman User

Berikut ini merupakan tampilan menu Pembayaran Hari ini Pada Halaman User dengan nama tampilpembayaran1.php :

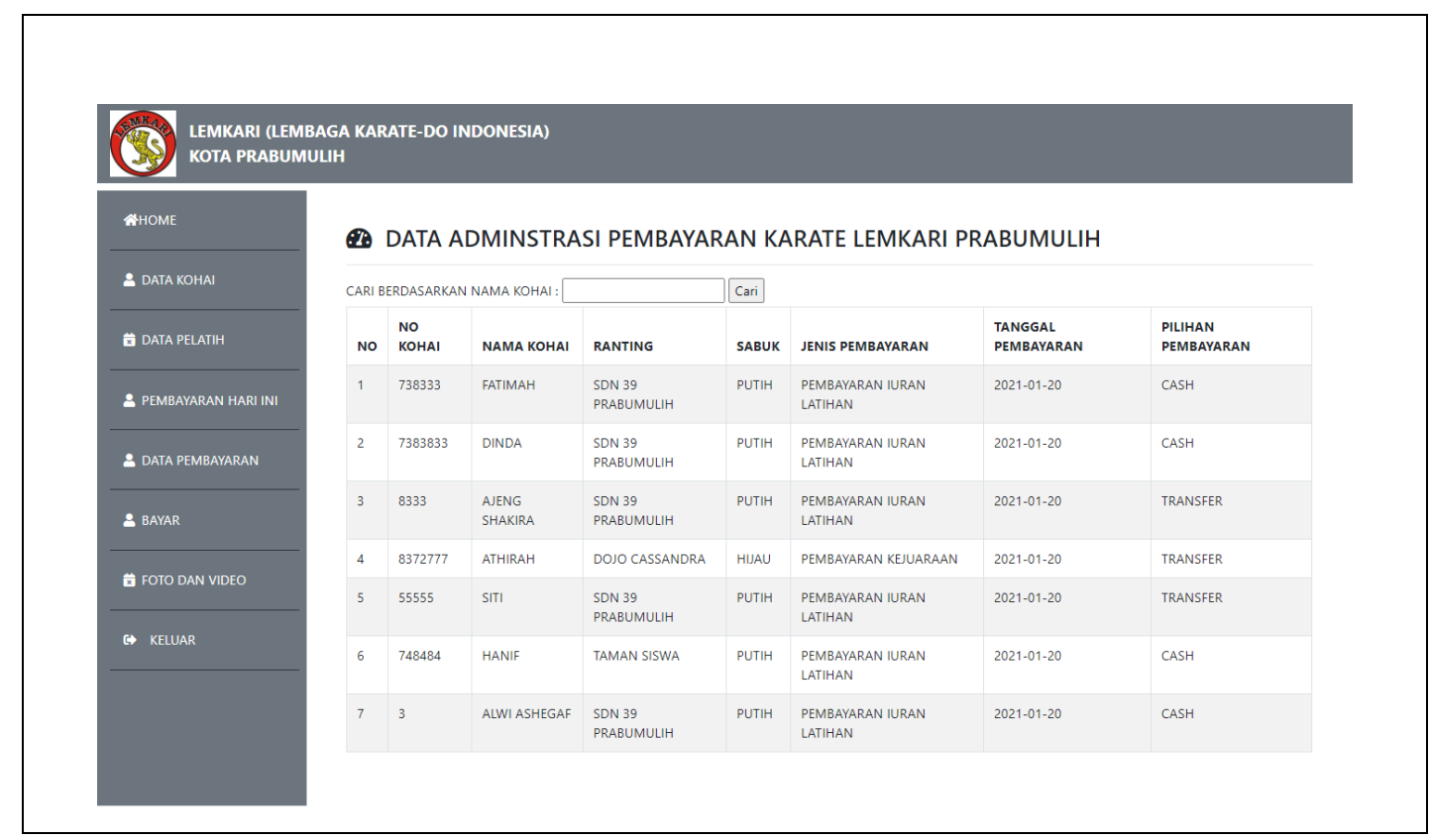

Gambar 4.9 Tampilan Menu Pembayaran Hari ini Pada Halaman User

Pada Tampilan Menu Pembayaran Hari ini Pada Halaman User ini merupakan sebuah halaman menu Pembayaran Hari ini Pada Halaman User. User dapat melihat data administrasi pembayaran hari ini dengan memilih menu Pembayaran Hari Ini. user dapat melihat data kohai/peserta yang sudah melakukan pembayaran secara cash ataupun transfer kepada rekening salah satu pelatih yang sudah tertera.

\section{Kesimpulan}

Berdasarkan analisis, desain dan implementasi perangkat lunak dan pembahasan sebelumnya, maka dapat ditarik kesimpulan dari Penelitian ini yaitu:

1. Perancangan sistem administrasi pembayaran ini dapat mengatasi kesulitankesulitan yang terdapat dalam sistem administrasi manual yang ada sebelumnya yaitu bila terjadi transaksi pembayaran, bagian pengurus mencatat pembayaran tersebut kedalam sebuah buku besar yang ditulis secara manual dan hanya melakukan rekapitulasi pencatatan pada Microsoft Office Excel saja

2. Sistem administrasi pembayaran karate pada Lemkari Prabumulih berbasis website akan memudahkan pelatih Lemkari Prabumulih untuk mengelola data administrasi pembayaran tanpa harus mencatat di buku besar dan tidak perlu lagi untuk melakukan rekapitulasi data administrasi pada Ms. Excel

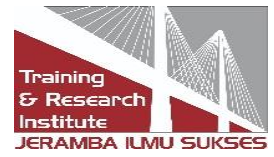


3. Metode perancangan yang digunakan pada penelitian ini menggunakan metode perancangan UML (Unifield Modelling Language) dengan menggunakan 3 diagram yaitu Use Case Diagram, Activity Diagram, dan Class Diagram.

\section{Referensi}

Antoni, D., Herdiansyah, M. I., Akbar, M., \& Sumitro, A. (2021). Pengembangan Infrastruktur Jaringan Untuk Meningkatkan Pelayanan Publik di Kota Palembang. JURNAL MEDIA INFORMATIKA BUDIDARMA, 5(4), 1652-1659.

Antoni, D., Jie, F., \& Abareshi, A. (2020). Critical factors in information technology capability for enhancing firm's environmental performance: case of Indonesian ICT sector. International Journal of Agile Systems and Management, 13(2), 159-181.

Antoni, D., \& Akbar, M. (2019). E-supply chain management value concept for the palm oil industry. Jurnal Sistem Informasi, 15(2), 15-29.

Antoni, D., Fikari, D., \& Akbar, M. (2018). The readiness of palm oil industry in enterprise resource planning. Telkomnika, 16(6), 2692-2702.

Fauzi, F., Dencik, A. B., \& Asiati, D. I. (2019). Metodologi Penelitian untuk manajemen dan akuntansi. Jakarta: Salemba Empat.

Abdur Rochman, dkk. (2018). Perancangan Sistem Informasi Administrasi Pembayaran SPP Siswa Berbasis Web di SMK Al-Amanah. JURNAL SISFOTEK GLOBAL, 8(1), 5156.

Andi Christian, Sebri Hesinto, Agustina. (2018). Rancang Bangun Website Sekolah Dengan Menggunakan Framework Bootstrap ( Studi Kasus SMP Negeri 6 Prabumulih ). CERITA, 6(1), 107.

Dedi Suhendro dan Trika Aprilila. (2017). Perancangan dan Implementasi Realisasi Anggaran Pendapatan (Studi Kasus : Pengadilan Negeri Klas IB Pematangsiantar). Seminar Nasional Teknologi Informatika, 30-36.

Dedi, dkk. (2019). Sistem Informasi Administrasi Kependudukan Berbasis Web di Kelurahan Sangiang Jaya . Seminar Nasional APTIKOM (SEMNASTIK), 306-313.

Fauzan, M. (2017). Komunikasi Instruksional Senpai Dalam Meningkatkan Prestasi Bertanding Atlit Karate Di Dojo Lc 41 Kota Pekanbaru. JOM FISIP, 4(1), 1-12.

Ganda Yoga Swara, Yunes Pebriadi. (2016). "Rekayasa Perangkat Lunak Pemesanan Tiket Bioskop Berbasis Web". Jurnal TEKNOIF, 4(2), 30.

Iwan Setiawan, dkk. (2018). Perancangan Sistem Administrasi Perumahan Pada PT.Gunung Berlian Nusantara Prabumulih. JUSIM, 3(1), 7-12.

Kadir, A. (2013). Pemograman Database MySQL Untuk Pemula. Yogyakarta: MediaKom.

Nurajizah, S. (2015). Sistem Informasi Perpustakaan Berbasis Web Dengan Metode Prototype: Studi Kasus Sekolah Islam Gema Nurani Bekasi. Prosiding SNIT, 215-216.

PRASTIYO, E. (2016). Analisa Dan Perancangan Sistem Informasi Kasir Pada Imc Barbershop Menggunakan Model Prototype. 1-11.

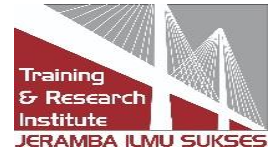


Putra, Y. I. (2015). I Jam Pasti Bisa Membuat Website Gratis Otodidak Tanpa Guru. Jakarta Selatan: SEALOVAMEDIA.

Raharjo, B. (2016). Modul Pemograman WEB (HTML, PHP, \& MySQL). Bandung: Modula.

Randi V. Palit, dkk. (2015). "Rancangan Sistem Informasi Keuangan Gereja Berbasis Web Di Jemaat GMIM Bukit Moria Malalayang". E-Jurnal Teknik Elektro dan Komputer, 4(7), 2.

Rhadian, M. (2018). Karate. Jakarta: PT Indahjaya Adipratama.

Riska Noviastuty, dkk. (2019). Perancangan Sistem Integrasi Administrasi Dan Keuangan Dalam Pelayanan Tera dan Tera Ulang Timbangan. TIARSIE, 16(2), 45-52.

Setiani Rafika, Ageng, dkk. (2017). " Sistem Pembayaran Rincian Biaya Kuliah Pada Perguruan Tinggi Raharja Menggunakan Go+ ". CERITA, 3(1), 66.

Wahyu Nugraha dan Muhamad Syarif. (2018). Penerapan Metode Prototype Dalam Perancangan Sistem Informasi Penghitungan Volume Dan Cost Penjualan Minuman Berbasis Website. JUSIM (Jurnal Sistem Informasi Musirawas), 3(2), 97-105.

Zul Azmi, dkk. (2018). "Memahami Penelitian Kualitatif Dalam Akuntansi". Jurnal Ilmu Akuntansi, 11(1), 160.

\section{Copyrights}

Copyright for this article is retained by the author(s), with first publication rights granted to the journal.

This is an open-access article distributed under the terms and conditions of the Creative Commons Attribution license (http://creativecommons.org/licenses/by/4.0/) 